\title{
Pembelajaran Menulis Teks Cerpen Melalui Teknik Parafrase Lagu Populer di Sekolah Menengah Atas
}

\author{
Prissilia Prahesta Waningyun, Sarwiji Suwandi, Budhi Setyawan \\ prissiliaprahesta06@student.uns.ac.id, sarwijiswan@staf.uns.ac.id, buset.74@gmail.com \\ Magister Pendidikan Bahasa Indonesia, FKIP, Universitas Sebelas Maret, Surakarta \\ Writing Short Story Using Paraphrasing Technique of Popular Song \\ for Senior High School Students
}

\begin{abstract}
This research aimed to improve the skill in writing a short story through paraphrasing technique of popular song using audio-visual media. This study used Classroom Action Research containing of two cycles. Each cycle consisted of three stages, namely planning, implementing, and assessing. The data collection instrument was the scoring rubric of writing skill and test items. The data were analyzed using comparative descriptive analysis by comparing the result of the initial condition, the first cycle, and the second cycle. The results revealed that paraphrasing technique could: 1) improve the skill in writing short story in which the improvement percentage of the writing skill is $70 \%$ for pre-cycle, $76 \%$ for the first cycle, and $80 \%$ for the second cycle; 2) improve the percentage of the number of the students passing the minimum score as many as $52 \%$ for the pre-cycle, $74 \%$ for the first cycle, and $87 \%$ for the second cycle.
\end{abstract}

Keywords: writing learning, short story text, paraphrasing technique

Received date: 30 Maret 2018

Article Info

Revised date: 17 April 2018

Accepted date: 4 Mei 2018

\section{PENDAHULUAN}

Standar Pendidikan Nasional yang tertulis dalam Peraturan Pemerintah Nomor 32 Tahun 2013 terkait Standar Proses menyatakan bahwa proses pembelajaran pada satuan pendidikan diselenggarakan secara interaktif, inspiratif, menyenangkan, menantang, memotivasi peserta didik untuk berpartisipasi aktif, serta memberikan ruang yang cukup bagi peserta didik untuk prakarsa, kreativitas dan kemandirian sesuai dengan bakat, minat dan perkembangan fisik serta psikologis. Setiap satuan pendidikan melakukan perencanaan, pelaksanaan dan penilaian dari proses pembelajaran untuk meningkatkan efektivitas dan efisiensi dari ketercapaian kompetensi lulusan. Maka dari itu, diperlukan usaha untuk menciptakan suatu pembelajaran yang interaktif, inovatif, dan menyenangkan untuk peserta didik melalui bimbingan guru.

Proses pembelajaran yang terangkum dalam Kurikulum 2013 harus menampilkan proses pembelajaran yang dapat menunjukkan peserta didik belajar dan berlatih mengembangkan pendekatan saintifik yang memberi dampak pada peningkatan hasil belajar peserta didik. Pemilihan sekolah dalam penelitian ini dikarenakan menjadi sekolah model yang dalam proses pembelajaran maupun prestasi belajar yang diraih oleh sekolah sudah cukup baik, namun pada kenyataannya masih ditemui beberapa kendala dalam proses pembelajaran salah satunya pembelajaran yang dilakukan masih konvensional dan belum menerapkan model pembelajaran yang inovatif dan kreatif. Prestasi belajar seseorang sesuai dengan tingkat keberhasilan sesuatu dalam mempelajari materi pelajaran yang nantinya dinyatakan dalam bentuk raport setelah mengalami proses belajar mengajar (Imanuel, 2017:13). 
Hal ini dapat mempengaruhi hasil belajar peserta didik. Hasil belajar adalah sesuatu yang didapat oleh peserta didik setelah melakukan aktivitas belajar (Djamarah dan Zain, 2006:10). Hasil belajar dapat ditunjukkan dengan nilai atau angka yang diberikan oleh guru kepada peserta didik, nilai inilah disimpulkan menjadi sebuah prestasi belajar sebagai hasil usaha yang telah dicapai peserta didik baik penguasaan materi, pengetahuan ataupun keterampilan (Hapsari, 2017:3).

Hasil pengamatan awal terhadap keterampilan menulis teks cerpen diperoleh presentase ketuntasan 52\% (16 siswa) dari 31 siswa yang telah melampaui batas Kriteria Ketuntasan Minimal (KKM). Oleh sebab itu, peneliti mengkaji dan meneliti lebih lanjut akan rendahnya keterampilan menulis teks cerpen pada peserta didik di Sekolah Menengah Atas.

Guru dan peneliti harus meningkatkan kualitas dari pengajaran dan pembelajaran menulis teks cerpen yang dilakukan di dalam kelas, salah satu cara dengan membuat peserta didik menjadi lebih aktif dan efektif dalam proses belajar mengajar sesuai dengan Kurikulum 2013 (Biliya, 2015:79). Penyajian pembelajaran menulis teks cerpen dengan teknik parafrase menjadi penyelesaian yang tepat sasaran, sehingga memudahkan peserta didik untuk mengembangkan ide dalam menulis teks cerpen.

Berdasarkan uraian di atas, permasalahan peneliti yang akan diselesaikan dalam Penelitian Tindakan Kelas (PTK) adalah apakah teknik parafrase dapat meningkatkan keterampilan menulis teks cerpen pada siswa secara bermakna.

\section{KAJIAN PUSTAKA}

\section{Pembelajaran Bahasa Indonesia di Sekolah Menengah Atas}

Pembelajaran adalah proses kombinatif yang interaktif dari berbagai komponen yang terlibat dalam pembelajaran untuk mencapai tujuan pembelajaran yang telah ditetapkan (Dirman dan Cicih, 2014:3). Pelaksanaan pembelajaran musti memiliki tujuan yang jelas, untuk mewujudkan cita-cita bangsa yang sesuai harapan. Undang-undang Nomor 20 Tahun 2003 tentang Sikdiknas mengatakan bahwa kurikulum adalah seperangkat rencana dan pengaturan terkait tujuan, isi, dan bahan pelajaran serta cara yang digunakan sebagai pedoman penyelenggaraan kegiatan belajar mengajar.

Pembelajaran Bahasa Indonesia ini didasarkan dari beberapa prinsip di antaranya, bahasa dipandang sebagai teks, pemilihan bentuk kebahasaan dalam mengungkapkan makna, bahasa bersifat fungsional dan bahasa disebut sarana pembentukan kemampuan berpikir. Bahasa Indonesia merupakan wahana untuk mengekpresikan pemikiran seseorang baik dalam bentuk lisan maupun tulisan (Nur'aini dkk, 2013:2).

Pembelajaran berbahasa Indonesia bertujuan untuk dapat menguasai empat keterampilan berbahasa, yakni menyimak, membaca, berbicara dan menulis. Pelaksanaan pembelajaran Bahasa Indonesia bertujuan agar siswa dapat memperoleh pengalaman menggunakan Bahasa Indonesia yang baik secara lisan maupun tulisan. Melalui kegiatan menulis inilah memberikan manfaat yang sangat penting bagi perkembangan dan pengaktualisasi diri siswa. Menulis adalah kegiatan proses berpikir yang kompleks dan rumit dimana memerlukan pengetahuan seseorang, kemampuan dasar yang dimiliki, strategi serta kemampuan untuk mengkoordinir proses yang terdiri dari banyak bagian (Hui, 2015:54).

Pembelajaran Bahasa Indonesia dalam Kurikulum 2013 memegang peran penting sebagai wahana pengetahuan (Subyantoro, 2014:184). Hal ini berimplikasi pada pemilihan bahan ajar yang sesuai dengan karakter Kurikulum 2013 yaitu bahan ajar yang membuat siswa mampu berekspresi secara bebas dan kreatif. Pihak guru sebagai fasilitator pembelajaran di kelas dan dengan adanya kurikulum 2013 ini guru dituntut untuk memilih dan menentukan strategi pembelajaran.

Strategi pembelajaran memiliki pola umum di mana kegiatan pengajar dan peserta didik dalam mewujudkan kegiatan pembelajaran untuk mencapai tujuan (Sufanti, 2014:26). 
Pembelajaran Menulis Teks Cerpen Melalui Teknik Parafrase Lagu Populer di Sekolah Menengah Atas (Prissilia Prahesta Waningyun, Sarwiji Suwandi, Budhi Setyawan)

Terdapat empat strategi pembelajaran yakni, 1) mengidentifikasi apa yang diharapkan, 2) memilih sistem pendekatan, 3) memilih dan menerapkan prosedur, metode, dan teknik pembelajaran, dan 4) menetapkan norma dan batas keberhasilan.

Usaha guru dalam menggunakan beberapa variabel pembelajaran baik itu tujuan, bahan, metode dan alat serta evaluasi merupakan sebuah tindakan nyata seorang guru di kelas dan dalam pengimplementasiannya menggunakan cara tertentu agar proses pembelajaran berlangsung efektif dan efisien (Sudjana, 2004:147). Tiga hal yang perlu guru perhatikan dalam melaksanakan strategi mengajar, 1) tahapan mengajar, 2) penggunaan model atau pendekatan mengajar, dan 3) penggunaan prinsip mengajar.

Proses pembelajaran Bahasa Indonesia ini diharapkan mendapatkan hasil yang maksimal dan peserta didik dapat mengikuti secara utuh setiap proses pembelajaran yang akan dilakukan. Oleh karena itu, proses pembelajaran yang dilakukan dalam penelitian ini meliputi a) Perencanaan, perencanaan pembelajaran disebut juga suatu aktivitas pengambilan keputusan secara rasional mengenai sasaran dan tujuan pembelajaran tertentu yang dapat berupa adanya perubahan perilaku dan rangkaian kegiatan pembelajaran dalam rangka pencapaian tujuan pembelajaran (Sanjaya, 2011:15). Perencanaan pembelajaran ini memerlukan desain pembelajaran yang merupakan pola dari rancangan pembelajaran yang disusun secara sistematis untuk menghasilkan berlangsungnya proses pembelajaran secara optimal. b) Pelaksanaan, pelaksanaan pembelajaran menulis teks cerpen ini guru telah menerapkan pendekatan scientific learning seperti yang tercantum di Kurikulum 2013. Penentuan strategi pembelajaran menulis teks cerpen juga sangat tepat. Strategi pembelajaran inilah merupakan pola-pola umum kegiatan pengajar dan peserta didik dalam mewujudkan kegiatan pembelajaran dan mencapai tujuan yang diharapkan (Sufanti, 2014:26). c) Penilaian, merupakan suatu kegiatan yang tidak mungkin dipisahkan dari kegiatan pembelajaran secara umum. Kegiatan penilaian merupakan kegiatan di akhir proses kegiatan pembelajaran. Hasil penilaian yang diperoleh, dari sini guru dapat mengetahui siswa mana yang bisa melanjutkan pelajaran dan dianggap berhasil menguasai materi, maupun siswa mana yang belum berhasil menguasai materi (Arikunto, 2012:15). Tanpa adanya suatu penilaian, guru tidak mungkin dapat menilai dan melaporkan hasil hasil pembelajaran siswa secara objektif.

\section{Keterampilan Menulis}

Kemampuan menulis lebih sulit untuk dikuasai dibandingkan ketiga keterampilan yang lain (Tarigan, 2008:8). Peserta didik banyak yang kesulitan mengusai keterampilan menulis dan menyebabkan kegiatan menulis harus sering dilatih secara terus menerus. Keterampilan menulis yang baik tidak secara instan didapatkan dari dalam diri siswa (Freedman dan Daiute, 2015:85). Seseorang akan menjadi terampil dalam menulis apabila orang tersebut menulis secara berulang-ulang (Ramdhanti, 2017:28). Menulis merupakan kegiatan aktualisasi pikiran manusia melalui kalimat dan paragraf yang runtut sehingga mudah dimaknai oleh khalayak umum (Fitriyanti dan Setyaningtyas, 2017:277). Menulis ialah kegiatan penyampaian ide, gagasan, pikiran, maupun parsaan kepada orang lain yang diwujudkan dalam bentuk tulisan sehingga orang lain dapat memahami maksud penulis dengan hanya membaca tulisan tersebut (Lestari, 2017:215). Dengan kata lain, kegiatan menulis ini memiliki tujuan untuk menyampaikan pesan atau informasi kepada orang lain dengan media yaitu bahasa tulis.

Prosedur menulis yang saat ini diterapkan melalui menulis model proses, meliputi tahap pramenulis, merancang, merevisi, mengedit dan memublikasi. (Andayani, 2015:193194). Menulis disebut kegiatan yang membutuhkan perencanaan untuk melakukannya dikarenakan menulis merupakan sebuah proses yang melalui serangkaian kegiatan (Hendriyanto, 2013:33). 
Salah satu bentuk teks yang diajarkan di Sekolah Menengah Atas adalah teks cerita pendek yang lebih disingkat cerpen. Teks cerpen ini tergolong dalam teks naratif yang mana model penceritaannya antara masalah dengan pemecahan masalah tidak menyatu dalam satu struktur teks melainkan terpisah dan berdiri sendiri (Mahsun, 2014:27). Senada dengan Dalman (2016:105) narasi adalah cerita. Cerita yang didasarkan pada urutan-urutan suatu atau (serangkaian) kejadian atau peristiwa. Dalam kejadian ini melibatkan tokoh dan tokoh ini mengalami atau menghadapi suatu konflik. Kejadian, tokoh, dan konflik ini merupakan unsur pokok dari suatu narasi dan ketiganya secara keseluruhan membentuk kesatuan yang disebut alur atau plot. Cerpen merupakan bentuk dari prosa rekaan yang pendek. Pendek disini masih mempersyaratkan adanya keutuhan cerita, bukan asal sedikit halaman (Siswanto, 2008:141).

Pemilihan teks cerpen di penelitian ini melihat kompetensi peserta didik yang cenderung kurang dalam keterampilan menulis, dengan adanya strategi pembelajaran yang dilakukan oleh peneliti diharapkan siswa mampu aktif dan kreatif untuk mengembangkan ide gagasan menjadi bentuk tulisan yakni teks cerpen.

\section{Teknik Parafrase}

Parafrase adalah suatu cara untuk memahami kandungan makna dalam suatu ciptaan sastra dengan jalan mengungkapkan kembali gagasan yang disampaikan pengarang dengan menggunakan kata-kata maupun kalimat yang berbeda dengan kata-kata dan kalimat yang digunakan pengarangnya (Aminuddin, 2010:41).

Prinsip dasar dari penerapan teknik parafrase pada hakikatnya berangkat dari pemikiran bahwa (1) gagasan yang sama dapat disampaikan lewat bentuk yang berbeda, (2) simbol-simbol yang bersifat konotatif dalam suatu cipta sastra dapat diganti dengan lambang atau bentuk lain yang tidak mengandung ketaksaan makna, (3) kalimat-kalimat atau baris dalam suatu cipta sastra yang mengalami pelesapan dapat dikembalikan lagi pada bentuk dasarnya, (4) pengubahan suatu bentuk cipta sastra baik dalam hal kata atau kalimat yang semula simbolik dan eliptis menjadi suatu bentuk kebahasaan yang tidak lagi konotatif akan mempermudah upaya seseorang untuk memahami kandungan makna dalam suatu bacaan, (5) pengungkapan kembali suatu gagasan yang sama dengan menggunakan media atau bentuk yang tidak sama oleh seorang pembaca akan mempertajam pemahaman gagasan yang diperoleh pembaca itu sendiri (Rohati, 2011:54).

Penelitian ini menggunakan lagu populer untuk memberikan stimulus kepada peserta didik dalam mengembangkan gagasan dan selanjutnya dituangkan dalam bentuk tulisan teks cerpen. Memparafrasekan lagu artinya mengubah lagu menjadi bentuk prosa/narasi tanpa mengurangi inti/makna dari lagu tersebut.

\section{METODE PENELITIAN}

Penelitian tentang pembelajaran menulis teks cerpen pada Kurikulum 2013 diadakan di SMA Negeri 5 Surakarta terletak di Jalan Letjen Sutoyo No. 18, Kelurahan Nusukan, Kecamatan Banjarsari, Kota Surakarta, Provinsi Jawa Tengah 57135 pada tahun pelajaran 2017/2018. Subjek penelitian adalah guru dan seluruh peserta didik XI IPS 2. Penelitian ini menggunakan pendekatan kualitatif deskriptif yang mana penelitian ini menggunakan pendekatan naturalistik untuk mencari dan menemukan pemahaman terhadap suatu fenomena dalam suatu latar dengan konteks tertentu (Moleong, 2016:5). Kualitatif deskriptif yakni dalam penelitian ini hanya menggambarkan objek permasalahan untuk mencapai kejelasan masalah yang akan dibahas, sehingga dapat diketahui apakah ada penyimpanganpenyimpangan dan selanjutnya digunakan sebagai dasar untuk membahasan permasalahan dalam penelitian ini. Teknik pengumpulan data pada penelitian ini yakni observasi, mengkaji dokumen, dan pemberian tes. Teknik observasi dilakukan dalam rangka mendapatkan data 
Pembelajaran Menulis Teks Cerpen Melalui Teknik Parafrase Lagu Populer di Sekolah Menengah Atas (Prissilia Prahesta Waningyun, Sarwiji Suwandi, Budhi Setyawan)

yang berasal dari peristiwa, kegiatan, tingkah laku, wilayah maupun gambar (Sutopo, 2006: 75). Kajian dokumen dilakukan dengan pencarian data melalui kajian dan analisis terhadap dokumen, baik tulis maupun gambar (Sukmadinata, 2015:221). Pada penelitian ini teknik yang digunakan adalah deskriptif komparatif (statistik deskriptif komparatif) dan teknik analisis kritis. Analisis komparatif merupakan metode umum seperti halnya eksperimen dan statistik (Suwandi, 2012:65). Data yang telah dikumpulkan dideskripsikan, dianalisis kemudian dibandingkan dengan hasil akhir setiap siklus dengan indikator keberhasilan. Hasil analisis kritis akan menunujukkan keunggulan dan kelemahan hasil kerja peserta didik dan guru pada saat pembelajaran menulis teks cerpen. Penelitian ini mengambil data berdasarkan informasi kinerja peserta didik dalam menulis teks cerpen, data kemampuan siswa dalam menghasilkan karya tulis berupa teks cerpen, dan semua dokumen kegiatan guru berupa Rencana Pelaksanaan Pembelajaran (RPP), data mengenai pelaksanaan pembelajaran di kelas termasuk strategi pelaksanaan pembelajaran di kelas. Tes yakni penilaian dalam bentuk tugas yang harus diselesaikan oleh peserta didik (Suwandi, 2011:47).

\section{HASIL DAN PEMBAHASAN}

Berdasarkan teori yang dijelaskan di atas, untuk mengetahui tingkat keberhasilan pembelajaran menulis teks cerpen di SMA Negeri 5 Surakarta, perlu melakukan pengamatan dan penganalisisan mulai dari tahap perencanaan, pelaksanaan hingga penilaian.

\section{Perencanaan Pembelajaran Menulis Teks Cerpen di SMA Negeri 5 Surakarta}

Perencanaan pembelajaran menulis teks cerpen meliputi beberapa kegiatan, kegiatan pertama dengan merancang skenario pembelajaran. Skenario pembelajaran ini dirancang untuk menyamakan pandangan tentang pembelajaran menulis teks cerpen melalui teknik parafrase, skenario pembelajaran ini disusun dan dilaksanakan untuk dua pertemuan. Pertemuan pertama guru menggali pengetahuan peserta didik tentang teks cerpen melalui kegiatan tanya jawab, guru membagi peserta didik menjadi kelompok besar yang selanjutnya melakukan kegiatan kerja kelompok membuat teks cerpen berdasarkan lagu populer yang telah dipersiapkan. Masing-masing anggota kelompok diminta untuk menyimak lagu populer yang ditayangkan oleh guru melalui LCD. Selanjutnya guru meminta siswa untuk mengonstruksi hasil diskusi kelompok ke dalam bentuk teks cerpen. Pertemuan kedua, guru melakukan evaluasi pembelajaran pertemuan pertama, yang selanjutnya guru menyuguhkan lagu populer dan peserta didik diminta membuat catatan kecil terkait lagu populer tersebut yang kemudian berdasarkan catatan kecil itu secara mandiri peserta didik menulis teks cerpen.

Kegiatan kedua yaitu menyusun Rencana Pelaksanaan Pembelajaran (RPP) yang disusun oleh guru kolaborator. Kegiatan ketiga mempersiapkan media pembelajaran. Perlu diperhatikan bahwa dalam menyusun RPP hendaknya telah menetapkan model pembelajaran yang sesaui dengan karakter materinya. Mawardi (2018: 30) menyatakan bahwa setiap model pembelajaran memiliki komponen-komponen model yang dapat dianalisis dan kemudian diimplementasikan dalam pembelajaran. Komponen-komponen itu mencakup: Syntax, Social System, Principles of Reaction, Support System, dan Instruction and Nurturant Effects. Guru kolaborator mempersiapkan tayangan power point berisi materi struktur teks cerpen, kaidah penulisan teks cerpen dan tahapan kegiatan menulis teks cerpen. Kegiatan keempat yaitu menyusun instrumen penelitian. Instrumen penelitian ini berupa rubrik penilaian keterampilan menulis teks cerpen. Pengukuran keterampilan menulis teks cerpen ini menggunakan instrumen penilaian dengan indikator penilaian isi teks, struktur teks, pemilihan kosakata, penggunaan kalimat dan mekanik tulisan. 


\section{Pelaksanaan Pembelajaran Menulis Teks Cerpen di SMA Negeri 5 Surakarta}

Pelaksanaan pembelajaran menulis teks cerpen dilakukan melalui beberapa kegiatan yakni, a) Kegiatan Pendahuluan, b) Kegiatan Inti dan c) Kegiatan Penutup.

Pada kegiatan pendahuluan ini guru memasuki kelas dan memberikan salam kepada peserta didik dilanjutkan dengan pengkondisian suasana kelas agar peserta didik kondusif dan menyenangkan selanjutnya guru melakukan pengecekan absesi peserta didik. Guru menyampaikan kompetensi dasar yang akan dicapai dan manfaatnya dalam kehidupan seharihari terkait teks cerpen. Guru menyampaikan materi pembelajaran dan tujuan pembelajaran yang hendak dicapai.

Kegiatan inti, pada kegiatan ini guru bertanya jawab kepada peserta didik terkait hakikat teks cerpen dan struktur teks cerpen. Peserta didik diberikan kesempatan untuk bertanya tentang kegiatan menulis teks cerpen bagi yang belum mereka pahami. Selanjutnya guru membagi peserta didik menjadi kelompok besar terdiri dari 5 peserta didik. Pembagian kelompok dilakukan secara demokratis yang terlebih dahulu didiskusikan bersama bagaimana teknik pembagian kelompok yang ingin dihendaki. Guru memberikan pengarahan kepada peserta didik mengenai mekanisme pelaksanaan pembelajaran teks cerpen dengan teknik parafrase lagu populer. Guru menampilkan lagu populer melalui tayangan video dan meminta peserta didik mencatat hal-hal yang penting. Masih dalam formasi kelompok, peserta didik menyampaikan hasil pemikiran mereka kepada anggota kelompok yang selanjutnya peserta didik menuliskan teks cerpen. Guru menunjuk 2 kelompok untuk mempresentasikan hasil kerja kelompoknya dan kelompok yang lain memberikan tanggapan. Setelah kerja kelompok, guru meminta peserta didik kembali ke tempat duduk masing-masing dan melakukan post test terkait penulisan teks cerpen secara individu, hasil post test peserta didik dikumpulkan melalui guru yang selanjutnya guru melakukan penilaian.

Kegiatan penutup, guru memberikan masukan kepada peserta didik akan presentasi hasil kerja kelompok. Guru memberikan fasilitas kepada peserta didik untuk merumuskan simpulan dan merangkum mengenai jalannya proses pembelajaran. Guru memberikan tugas individu kepada peserta didik serta mendiskusikan batas waktu pengumpulan tugas individu tersebut. Guru menutup kegiatan dengan mengucapkan salam.

\section{Penilaian Pembelajaran Menulis Teks Cerpen di SMA Negeri 5 Surakarta}

Penilaian pembelajaran menulis teks cerpen dilakukan dengan menilai setiap indikator penilaian mulai dari isi teks, struktur teks, penggunaan kosa kata, penguasaan kalimat dan mekanik tulisan. Rata-rata hasil keterampilan menulis teks cerpen melalui teknik parafrase lagu populer pada setiap siklus tindakan digambarkan secara rinci pada diagram batang di bawah ini.

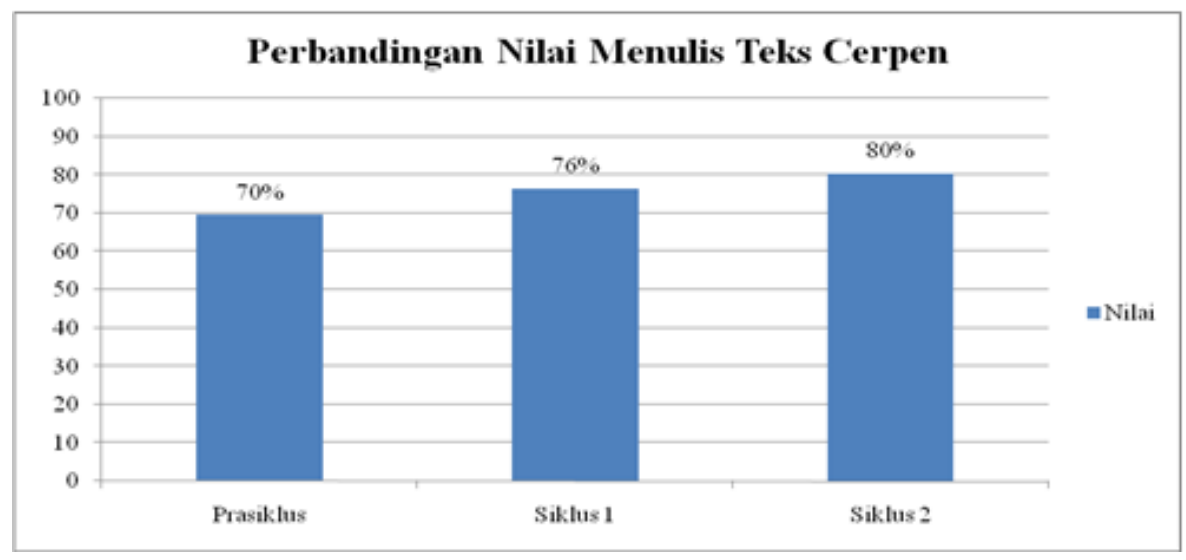

Gambar 1.

Perbandingan Nilai Menulis Teks Cerpen 
Pembelajaran Menulis Teks Cerpen Melalui Teknik Parafrase Lagu Populer di Sekolah Menengah Atas (Prissilia Prahesta Waningyun, Sarwiji Suwandi, Budhi Setyawan)

Data di atas menunjukkan bahwa telah terjadi peningkatan nilai rata-rata keterampilan menulis teks cerpen dari tahap prasiklus, siklus 1 dan siklus 2. Nilai rata-rata keterampilan menulis peserta didik pada tahap prasiklus adalah 70\%. Setelah mendapatkan tindakan dengan penerapan teknik parafrase dalam menulis teks cerpen mengalami peningkatan menjadi $76 \%$ dan terus mengalami peningkatan pada siklus 2 mencapai $80 \%$. Peningkatan dapat dilihat dari kualitas tulisan peserta didik di mana mengalami peningkatan setiap siklusnya. Peningkatan ini dilihat dari indikator penilaian, yaitu isi teks, struktur teks, penggunaan kosa kata, penguasaan kalimat dan mekanik tulisan. Data diagram batang di atas menunjukkan bahwa nilai presentase rata-rata siklus 1 lebih tinggi dibandingkan prasiklus. Nilai presentase rata-rata siklus 2 juga mengalami peningkatan dibandingkan dengan nilai siklus 1. Dengan demikian teknik parafrase lagu populer dapat meningkatkan keterampilan menulis teks cerpen pada peserta didik.

\section{Pembahasan}

Penggunaan teknik parafrase lagu populer ini bermaksud mengurangi kejenuhan peserta didik selama mengikuti proses pembelajaran menulis teks cerpen. Pembelajaran Bahasa Indonesia dianggap mudah sehingga terkadang beberapa peserta didik enggan untuk memperhatikan pembelajaran secara seksama. Penyampaian materi yang tergolong tidak seperti biasanya membuat peserta didik lebih tertarik dan antusias mengikuti proses pembelajaran. Penggunaan lagu populer dipilih secara selektif dengan memperhatikan lirik lagu mengandung konten pendidikan karakter dinilai mampu menarik perhatian serta membuat peserta didik lebih mudah menemukan ide ataupun gagasan yang akan ditulis ke dalam teks cerpen.

Hasil penelitian ini menunjukkan bahwa pengunaan teknik parafrase lagu populer dalam kegiatan pembelajaran Bahasa Indonesia sangat efektif untuk meningkatkan keterampilan menulis teks cerpen. Hal ini dibuktikan dengan adanya peningkatan hasil pretest dan posttest dari jumlah sampel yaitu 31 peserta didik.

\section{SIMPULAN DAN SARAN}

Hasil pembahasan di atas, maka dapat ditarik simpulan bahwa teknik parafrase dapat meningkatkan prestasi belajar pada siswa kelas XI IPS 2 SMA Negeri 5 Surakarta. Diketahui bahwa penerapan teknik parafrase menggunakan lagu populer membuat peserta didik menjadi lebih terampil dalam mengembangkan ide atau gagasan yang dituangkan ke dalam sebuah teks yaitu teks cerpen. Pembelajaran ini mengalami peningkatan di tiap tahapannya mulai dari nilai yang diperoleh di prasiklus mencapai presentase ketuntasan $70 \%$, meningkat pada siklus 1 yakni $76 \%$ dan mengalami peningkatan pada siklus 2 yakni $80 \%$.

Oleh karena itu penulis menyarankan: 1) guru agar lebih kreatif mengembangkan pembelajaran menulis teks cerpen melalui teknik parafrase dengan pemanfaatan lagu populer agar peserta didik lebih termotivasi untuk lebih giat belajar sehingga dapat meningkatkan prestasi belajar yang dicapai oleh peserta didik, 2) pihak sekolah harus berperan aktif dengan memberikan fasilitas yang memadai untuk berlangsungnya pembelajaran menulis teks cerpen melalui teknik parafrase lagu populer agar berlangsung pembelajaran yang interaktif dan inovatif.

\section{UCAPAN TERIMAKASIH}

Penelitian dan penyususnan artikel jurnal ini tidak terlepas dari bantuan berbagai pihak. Penulis mengucapkan terima kasih kepada:

1. Prof. Dr. Andayani, M.Pd, selaku Kaprodi Magister Pendidikan Bahasa Indonesia, FKIP UNS. 
2. Prof. Dr. Sarwiji Suwandi, M.Pd, selaku dosen pembimbing yang telah memberikan arahan, bimbingan, dan motivasi kepada penulis.

3. Dr. Budhi Setyawan, M.Pd, selaku dosen pembimbing yang dengan penuh kesabaran memberikan bimbingannya.

4. Sajidan, S.Pd, M.Pd, selaku Kepala SMA Negeri 5 Surakarta, yang telah memberikan kesempatan kepada penulis untuk melakukan penelitian di SMA Negeri 5 Surakarta.

5. Sumiyati, S.Pd, selaku guru bahasa Indonesia yang telah bersedia memberikan kesempatan kepada penulis untuk melakukan penelitian mengenai pelaksanan pembelajaran menulis teks cerpen di kelas XI SMA Negeri 5 Surakarta.

6. Berbagai pihak yang tidak dapat penulis sebutkan satu persatu.

Penulis berdoa semoga amal kebaikan yang telah diberikan, mendapatkan limpahan pahala dari Tuhan Yang Maha Esa.

\section{DAFTAR PUSTAKA}

Aminuddin. 2002. Pengantar Apresiasi Karya Sastra. Bandung: Sinar Baru.

Andayani. 2015. Problematika Aksioma dalam Pembelajaran Bahasa Indonesia. DIY: Deepublish.

Arikunto, Suharsimi. 2012. Dasar-Dasar Evaluasi Pendidikan. Jakarta: PT Bumi Aksara.

Biliya A, Betty. 2015. Penerapan Model Open Ended untuk Meningkatkan Keterampilan Proses dan Hasil Belajar Siswa Kelas V SDN 1 Repaking-Wonosegoro-Boyolali. Scholaria: Jurnal Pendidikan dan Kebudayaan, 5 (1), 78-91.

Dalman. 2016. Keterampilan Menulis. Jakarta: PT. RajaGrafindo Persada.

Dirman, Junarsih, Cicih. 2014. Kegiatan Pembelajaran yang Mendidik dalam Rangka Implementasi Standar Proses Pendidikan. Jakarta: PT Rineka Cipta.

Departemen Pendidikan Nasional. 2003. Undang-Undang Nomor 20 Tahun 2003 tentang Sistem Pendidikan Nasional. Jakarta.

Djamarah dan Zain. 2006. Strategi Belajar Mengajar. Jakarta: Rineka Cipta.

Hapsari, Agni Era. 2017. Penerapan Model Pembelajaran Kooperatif Tipe Numbered Heads Together Berbantu Media Interaktif untuk Meningkatkan Aktivitas dan Prestasi Belajar Siswa. Scholaria: Jurnal Pendidikan dan Kebudayaan, 7 (1), 1-9.

Fitriyanti, Retno dan Euninice, Widyanti Setyaningtias. 2017. Pengaruh Metode Chain Writing Terhadap Hasil Belajar Menulis Siswa Kelas 3 Sekolah Dasar. Scholaria: Jurnal Pendidikan dan Kebudayaan, 7 (3), 276-282.

Freedman, Sarah Warshauer. Dauite, Colette. 2015. Instructional Methods and Learning Activities In Teaching Writing. Emerald Insight. 8. 83-110.

Hendriyanto, Agoes. 2013. Menulis Ilmiah: Teori dan Praktik. Surakarta: Pelangi Press.

Hui, Nguyen Thanh. 2015. Model-Model Pengajaran dan Pembelajaran: Isu-Isu Metodis dan Paragdimatis. Jogjakarta: Pustaka Pelajar.

Imanuel W, Darius. 2017. Peran Jam Belajar Efektif Siswa di Sekolah dalam Memoderatori Motivasi dalam Meningkatkan Hasil Belajar Siswa. Scholaria: Jurnal Pendidikan dan Kebudayaan, 7 (1), 10-16. 
Pembelajaran Menulis Teks Cerpen Melalui Teknik Parafrase Lagu Populer di Sekolah Menengah

Atas (Prissilia Prahesta Waningyun, Sarwiji Suwandi, Budhi Setyawan)

Lestari, Tri Arum, Mudzanatun, dan Damayani, Aries Tika. 2017. Keefektifan Media Audio Visual sebagai Kreativitas Guru Sekolah Dasar dalam Menumbuhkan Keterampilan Menulis Puisi Siswa. Scholaria: Jurnal Pendidikan dan Kebudayaan, 7 (3), 214-225.

Mahsun. 2014. Teks dalam Pembelajaran Bahasa Indonesia Kurikulum 2013. Jakarta: RajaGrafindo Persada.

Mawardi, M. (2018). Designing the Implementation of Model and Instructional Media. Scholaria: Jurnal Pendidikan dan Kebudayaan, 8(1), 26-40.Moleong, Lexy J. 2016. Metodologi Penelitian Kualitatif. Bandung: PT Remaja Rosdakarya.

Nur'aini, dkk. 2013. Implementasi Kurikulum 2013 pada Pembelajaran Teks Eksposisi, Studi Kasus di Kelas X SMKN 1 Karanganyar. Basastra: Jurnal Penelitian Bahasa, Sastra Indonesia dan Pengajarannya. 3 (3). 1-17

Permendikbud Nomor 22 Tahun 2016 tentang Standar Proses Pendidikan Dasar dan Menengah. Jakarta: Depdiknas.

Permendikbud Nomor 23 Tahun 2016 tentang Standar Penilaian Pendidikan. Jakarta: Depdiknas.

Ramadhanti, Dina. 2017. Penerapan Model Kooperatif Tipe Circ dalam Pembelajaran Menulis Narasi Siswa Kelas VII SMP N 2 Lembah Gumanti. Jurnal Gramatika. 3 (il). 27-42.

Rohati. 2011. Strategi Pembelajaran Keterampilan Bahasa Terpadu dengan Teknik Parafrase untuk Meningkatkan Kemampuan Apresiasi dan Menulis Puisi. 2 (1). ISSN 1412565X. Jurnal Universitas Pendidikan Indonesia.

Sanjaya, Wina. 2011. Strategi Pembelajaran Berorientasi Standar Proses Pendidikan. Jakarta: Kencana Prenada Media.

Siswanto, Wahyudi. 2008. Pengantar Teori Sastra. Jakarta: Grasindo.

Subyantoro. (2014). Teori Pembelajaran Bahasa, Implementasi Psikolinguistik Pendidikan. Semarang: UNNES Press.

Sudjana, Nana. 2014. Penilaian Hasil Proses Belajar Mengajar. Bandung: Remaja Rosdakarya.

Sufanti, Main. 2014. Strategi Pengajaran Bahasa dan Sastra Indonesia. Surakarta: Yuma Pustaka.

Sukmadinata, Nana Syaodih. 2015. Pengembangan Kurikulum Teori dan Praktik. Bandung: Remaja Rosdakarya.

Sutopo. 2006. Metodologi Penelitian Kualitatif. Surakarta: UNS Press.

Suwandi, Sarwiji. 2011. Model-Model Asesmen dalam Pembelajaran. Surakarta: Yuma Pustaka.

. 2012. Penelitian Tindakan Kelas dan Penulisan Karya Ilmiah. Surakarta: Yuma Pustaka.

Tarigan, Henry Guntur. 2008. Menulis sebagai Suatu Keterampilan Berbahasa. Bandung: Angkasa. 